\title{
Development of digital literacy in basic education through virtual classes derived from Covid-19
}

\section{Desarrollo de la literacidad digital en educación básica mediante clases virtuales derivadas del Covid-19}

GARZA-ROSALES, Gerardo de Jesús †**, VARGAS-LERMA, Jorge Fernando, MIRÓN-OROZCO Víctor Ilich and MARTÍNEZ-VILLALBA, José Antonio

Centro de Investigación e Innovación para el Desarrollo Educativo, Durango, Universidad Iberoamericana Torreón, Mexico.

ID $1^{\text {st }}$ Author: Gerardo de Jesús, Garza-Rosales / ORC ID: 0000-0003-2641-6402, CVU CONACYT ID: 640612

ID $1^{\text {st }}$ Coautor: Jorge Fernando, Vargas-Lerma / ORC ID: 0000-0003-2232-1289 CVU CONACYT ID: 1097718

ID $2^{\text {nd }}$ Coautor: Víctor Ilich, Mirón-Orozco / ORC ID: 0000-0001-9766-6463 CVU CONACYT ID: 209624

ID $3^{\text {rd }}$ Coautor: José Antonio Martínez-Villalba / ORC ID: 0000-0003-4878-3692, CVU CONACYT ID: 367732

DOI: $10.35429 /$ JCSI.2020.18.6.28.38

Received September 01, 2020; Accepted December 10, 2020

\begin{abstract}
Abtract
Globally, education changed dramatically due to the SARS-CoV-2 virus pandemic. Consequently, literacy became important as an adaptive response measure of basic education students in virtual classes. In this research, it analyzes the development of digital literacy as an effective tool in the teaching-learning process in virtual education. For them, an evaluation instrument with 40 variables on a ratio scale and 5 on a nominal scale (final Cronbach's alpha of 0.950) is used. This instrument was applied to basic education teachers in Oaxaca, Aguascalientes and Durango. Statistical test was performed to determine the factor analysis and ANOVA in order to find the main variables that are related to digital literacy in the three selected states. The main conclusions were: 1) the teachers overcame the difficulties in the use of virtual platforms and digital media during the pandemic and, 2) they achieved the understanding of the contents by the students. Greater emphasis is suggested on monitoring and evaluating distance education in order to find viable strategies according to the needs of the students
\end{abstract}

Resumen

A nivel mundial la educación cambió drásticamente debido a la pandemia por el virus SARS-CoV-2. A consecuencia, la literacidad se volvió importante como una medida de respuesta adaptativa de los estudiantes de educación básica en las clases virtuales. Esta investigación busca analizar el desarrollo de la literacidad digital como una herramienta eficaz en el proceso enseñanzaaprendizaje en la educación virtual. Para ello se utiliza un instrumento de evaluación con 40 variables en escala razón y 5 variables nominales (alfa de Cronbach final de 0.960). El instumento fue aplicado a docentes de educación básica en los estados de Oaxaca, Aguascalientes y Durango. Se realizaron pruebas estadísticas para análisis de factores y un ANOVA con la finalidad de encontrar las principales variables que se relacionen con la literacidad digital en los tres estados seleccionados. Entre los principales hallazgos se encuentran: 1) los docentes superaron las dificultades en el uso de las plataformas virtuales y medios digitales durante la pandemia, y 2) lograron la comprensión de los contenidos por parte de los estudiantes. Se suguiere mayor énfasis en el monitoreo y evaluación de la educación a distancia con el objetivo de encontrar estrategias viables según las necesidades de los estudiantes.

Literacidad, Educación virtual, COVID-19

\footnotetext{
* Author Correspondence (e-mail: gerardo.garzar@ durango.gob.mx)

$\uparrow$ Researcher contributing as first Author.
} 


\section{Introduction}

At the beginning of the year 2020 with the arrival of the SARS-CoV-2 virus that causes the COVID-19 disease, the normal development of each country began to take a drastic turn in different perspectives of daily life. One of the most affected aspects was education, where teachers and students found it necessary to change their classes in person to work through various digital platforms. The sudden adaptation to the virtual modality implied a series of changes and adaptations in the teaching and learning processes, mainly in the use of virtual media. It is important to note that interacting with digital media is a process that does not necessarily require a formal educational context, in fact, the appropriation of devices, programs and information systems could occur through non-formal educational contexts of trial and error. This form of learning takes up constructivist aspects and proposes a coherent way of how the teacher and / or student can instrumentally appropriate digital technology.

In this sense, the important thing is not to identify, but to know how to train teachers and guide students, so that apart from being users of the internet or of various digital devices, they know how and when to use audiovisual media correctly. In both cases, it is important to promote an intellectual growth focused on academics and professionals, it is to learn to use digital resources and media for education with the help of learning in literacy. For the educational context, knowing how, for what and how much students and teachers use technologies at different educational levels is a priority today. We talk about audiovisual resources and media every time they are more systematized with a person's daily life, causing them to be placed in a position where it is easier to fall on the side of leisure and entertainment, instead of personal, academic or training. professional.

The importance of continuing to address issues related to digital media in education lies in the use of these to carry out academic activities. The global health emergency caused by the COVID-19 disease is forcing educational institutions to implement the use of technology as an unprecedented academic lifestyle, for which in the educational field the main actors had to rethink each one of them. their teaching and learning strategies.
In the present research work, an analysis was carried out about the development of literacy in students of basic education, through digital media, during virtual education derived from the COVID-19 pandemic. A comparison is presented in three states of the Mexican Republic, one in the north (Durango), the center (Aguascalientes) and the south (Oaxaca) to know how the educational process was during this school period in terms of the use of technology and literacy development.

\section{Study Background}

\subsection{Literacy}

At first, reading and writing in the history of mankind has been associated with the literacy process, although this term has only been related to learning a technique to decode a certain written system that states that for the Romans "Reading was giving his voice back to the text" (Ferreiro 1997).

The educational situation faces an important challenge, the transition from classroom teaching to digital. In this context, institutions such as the OECD (Organization for Economic Cooperation and Development) are conducting numerous studies by collecting data and analyzing to face this transformation, coordinating in turn, policies that allow addressing this important challenge with alternatives that provide strategies for this transition (OECD, 2018).

In this way, the practices of reading and writing have been simplified to the oralization of linguistic signs (linguistic approach) or the interpretation of the text from the cognitive abilities of the reader (psycholinguistic approach). However, it is important to understand literacy as a set of social practices, in which reading and writing are thought of as social tasks (Barton, et al., 2000).

Ferreiro (1995) argues that reading and writing have social uses, since it is not reduced to the interpretation and production of graphic marks, but the culture of writing is present in the daily life of the human being. On the other hand, for Cassany (2005) the understanding of written codes is understood as a social act that brings together the set of individual interpretations that constitute the collective meaning. 
Regarding the social practices of language in digital spaces, Cassany (2003) describes and analyzes the impact of new technologies on the domestic and academic literate practices of a group of Mexican adults who work abroad, seeking to categorize them according to a type user of ICTs (Information and Communication Technologies). This new reception process is translated into new learning based on collaboration, active involvement and, ultimately, an interactive relationship that directly affects communication between the instructor and the students, thanks to the new spaces and new tools offered by the internet.

Similarly, it is pertinent to understand that contemporary reading and writing take as a starting point the interpretation of individuals for the construction, which, from a given community, is made of the culture of writing. Thus, Freire (2004) states that "literacy has to do with individual and class identity, it has to do with the formation of citizenship".

From the previous approach, literacy is related to criticality competence, which is required in the formation of society. Taking into account the literacy-democracy relationship, Pérez (2004) places some functions of the school as a setting for the development of political consciousness, since reading and writing from the perspective of sociocultural practices require the exercise of society.

Learning a language implies the recognition of a common space for the citizens of a certain community. Ferreiro (2013) recognizes that when the child enters the culture of writing, skills and competencies in reading and writing are built to strengthen participation and development of autonomy. Although, it should be taken into account that this concept focuses on literacy processes, differing from the conception of reading and writing as literacy practices.

Furthermore, the emergence of ICTs has generated transformations in social practices, that is, the culture of writing has evolved and new reading guidelines have emerged. Ferreiro (2013) maintains that "there are new demands towards the reader. The reader in search of information lacks the indicators, built over centuries of editorial practice, that allow giving reliability to a text before being read".
The previous approach invites us to think about the new forms and mediations by the teacher to generate new alternatives to the social practices of language.

Faced with the challenges posed by the new ways of reading and writing, Levrato (2014) emphasize that in internet media literacy a new culture begins, identifying the forms, practices and perceptions of digital reading. In addition, there is critical reflection, media transition, humanism and creativity.

It is important to highlight that literacy is linked to digital contexts, since a person in his wake at different academic levels develops search, analysis, criticism and comprehension skills due to the tasks that are presented to him.

From this new perspective, literacy forces us to rethink how the social dynamics around reading and writing open ways to reconfigure the meaning of the social practices of language that circulate in school, emphasizing the interactions of the subjects and their relationship with culture.

\subsection{Digital media}

The progress of the initiatives that the education sector has carried out in the use and incorporation of digital media and computer technology in schools can be observed in: 1) level of availability and use of technology, 2) innovation in environments of learning, 3) content design and production, 4) development of didactic strategies, 5) application in the classroom and, 6) the impact obtained. Attention can be transferred from the classroom to the student, making a different pedagogical effort; which includes the organizational structure of human, administrative and teaching teams. The foregoing to achieve educational attention at least as good as the face-to-face one in the current classroom (González, 2011).

The digital medium (audiovisual) for Moore (1996), is part of the didactic resources called multisensory and tries to approximate teaching to direct experience using perception, hearing and sight as channels. In this way, the audiovisual medium recreates images, words and sounds. The supports can be both printed and electronic; for example: photography, film, radio, television, comics. 
Audiovisual media are becoming accessible to everyone and have increasing power with families within their homes and in educational institutions. Reason why, it implies a great challenge for the educational system in general.

In this sense, McLuhan (2011) mentions that written language can be accessed not only through the book, but also with camera movements, gestures, photographic or digital montages. Likewise, he brings language closer to its true, more complete social reality, transcends the oral, adds the possibility of sound, gestural symbols, all kinds of reality, including virtual reality; the creativity of the human race and the technical advances that make the earth a world without communication borders.

One of the positive aspects, a result of this paradigm shift in the development of training experiences and the implementation of technological tools or resources for online teaching during the COVID-19 pandemic, has been the internationalization of learning by promoting, and very actively implement collaborative and interdisciplinary actions online, favoring global citizenship and community impact (Martín-Barbero, 2020).

\subsection{Virtual education}

In relation to the global pandemic generated by COVID-19 and the social distancing that it implies, there is no other option than to adapt to virtual education to give continuity to educational processes. The fact that managers and teachers develop digital skills for the management of resources that are useful in their classes and of benefit to students becomes relevant.

Virtual education is an educational method or system of independent training, not face-to-face, mediated by various technologies. Specialists define it as planned teaching and learning, teaching occurs in a different place than learning, it requires communication through technologies and special institutional organization (Nieto, 2012).

Virtual education changes traditional patterns in the teaching-learning process, for both the teacher and the student, there is no direct relationship in real time.
Student learning is more flexible, there is no physical coincidence in terms of place and time, it demands greater independence and selfregulation on the part of the student body. In the same way, it adopts various peculiarities depending on the intermediation, the time and the channel to be used.

The information and knowledge society demand continuous learning throughout life, this is not alien to the educational institution in charge of the initial and continuous training of education professionals. Therefore, the revision of the curricular contents is imposed to determine if the knowledge, abilities and skills that are intended to be developed in the students are those required by today's society, if they respond to the internationalization of the economy, to the new economic blocks, to international trade, to the new human sensitivity and to the problems of man in general.

Teachers have reacted to the new emergency situation posed by COVID-19 by opting for known, learned or contributed resources by their universities or educational institutions, in addition to attending to the various learning styles and methodologies that allow promoting the acquisition of skills . Knowing these telematic tools, virtual spaces, usability, as well as the impact on learning, is of great relevance to obtain an overview of best practices, in favor of a correct transformation of universities, institutions and educational centers to virtual teaching. For this reason, it is highly significant to identify how the training of teachers has been for their development and implementation of these new teaching processes and how the different learning spaces have been adapted (Mampaso and Carrascal, 2020).

In correspondence with the approach offered by García (2014), one of the fundamental difficulties for the teacher to assume the role that corresponds to him in virtual education is in the contradiction between the traditional training he has received and the new context of education. At the same time, the completion of these competencies and the training processes that guarantee the active, reflective, creative, responsible and contextualized learning of the student have not been prioritized with the aim of acquiring competences in accordance with the curricula and social demands . 
Based on this context, various problems often arise. Students may carry out superficial and incomplete learning, get distracted by online games and not focus on the objectives set; therefore, a rejection of virtual training as a valid learning method has a negative effect. Other disadvantages are quality and unresolved technical problems, due to the lack of reliability of online exams.

According to Dorfsman (2012), with the advances in society related to information, teaching undergoes transformations that correspond to the acquisition of new skills and that are in correspondence with the so-called digital dimension. Likewise, it is linked to the impact they have on teaching, the components of the information society and that will enable teacher training in the following aspects: 1) produce their own content and expand it, 2) share their tasks with colleagues and students, 3) exceed local and institutional frameworks, 4) design work spaces, creativity, cooperation, encounter and reflection, 5) generate, participate and lead teaching-learning communities, 6) research, 7) production, and 8) recreation with colleagues, students and interested public in general.

"Move freely through the real and virtual world, thereby consolidating their social, cultural and professional potential" (Dorfsman, 2012). This process requires time and certain objective conditions that guarantee the adequate preparation of teachers; as well as subjective conditions that are related to the understanding of the need and importance of distance education. The challenge is to renew educational methods that allow adequate planning of the teaching-learning process, that are capable of mastering new technologies, provide information in an understandable way about their teaching work, maintain close communication with students in an audiovisual way and with text simultaneously, teach to search, analyze and facilitate learning.

Finally, we can establish that "The model of teaching and learning in virtual education will be applicable in an educational institution where the learning contents are articulated to the study plans and that these, in turn, are integrated into the institutional strategic plans and academic units "(Domínguez et al., 2013).

\section{Methodology}

The objective of the research was to analyze the development of literacy in basic education students, through digital media, during virtual education derived from the COVID-19 pandemic; making a comparison in three states of the Mexican Republic, one in the north (Durango), the center (Aguascalientes) and the south (Oaxaca).

\subsection{Participant profile: Talk about the population and sample}

The study population considered basic education teachers from Mexico since the entire country is affected by the pandemic. Most of the teachers found it necessary to work synchronously and asynchronously in a virtual way, in some educational institutions in the first months in which the quarantine began, classes were taught $80 \%$ virtual and $20 \%$ face-to-face. The latter were required in the middle of the year that due to the critical contagion situation it was only virtual.

The sample that was selected for the study considers three states, this to compare the educational situation in the north (Durango), the center (Aguascalientes) and the south (Oaxaca). from the country. This allows an overview of virtual education using digital media.

\subsection{Assessment instrument}

This divided into five nominal variables. The first indicates the state to which they belong, considering Oaxaca, Aguascalientes and Durango. Subsequently, the gender of the interviewee, the level of study, the years of service and finally the degree they teach is considered.

There are also interval variables that are divided into three parts, the first corresponds to digital media, where variables such as knowledge and use of technology, the technological conditions of teachers and students, counseling are established. from educational authorities to teachers in the use of technology. The second section corresponds to digital literacy, where variables are established that consider the pedagogical aspects of reading comprehension and issues related to the social practices of language. 
The last section of the instrument focuses on virtual education considering elements of educational practice, such as planning, application, development and evaluation. Se aplicaron dos pruebas piloto. Se aplicó un instrumento de 40 indicadores por medio de Google Formularios enviados por vía WhatsApp a 20 docentes, donde las respuestas estaban diseñadas en base a la escala de medición de 0 al 100; en donde el 0 indicaba la ausencia del aspecto que se está evaluando y el 100 el valor máximo que se puede otorgar. Finalmente se obtuvo un Alpha de Cronbach de .96 según el programa STATICS (Hernández et al., 2018) La información recabada de la aplicación de los instrumentos, se analizó mediante el programa de STATISTICA considerando: análisis de factores y el análisis comparativo ANOVA.

\subsection{Análisis de factores}

Se utilizó factores, el cual es una "técnica de reducción de la dimensionalidad de los datos. Que sirve para encontrar grupos homogéneos de variables a partir de un conjunto numeroso de variables" (De la Fuente, 2011). En este estudio se seleccionaron 40 variables, con un máximo número de 10 factores y un factor de carga de $\alpha=$ .95 , además como principal factor de análisis comunalidades $=$ múltiple $\mathrm{R}^{2} \mathrm{y}$ el factor de rotación Varimax normalizada (De la Fuete, 2011).

\subsection{Análisis comparativo}

Two pilot tests were applied. An instrument of 40 indicators was applied through Google Forms sent via WhatsApp to 20 teachers, where the responses were designed based on the measurement scale from 0 to 100 ; where 0 indicated the absence of the aspect being evaluated and 100 the maximum value that can be granted. Finally, a Cronbach's Alpha of .96 was obtained according to the STATICS program (Hernández et al., 2018) The information collected from the application of the instruments was analyzed using the STATISTICA program considering: factor analysis and comparative analysis ANOVA.

\subsection{Factor analysis}

Factors were used, which is a "technique for reducing the dimensionality of the data. Which is useful to find homogeneous groups of variables from a large set of variables "(De la Fuente, 2011).

ISSN-2444-5002

ECORFAN $^{\circledR}$ Todos los derechos reservados
In this study, 40 variables were selected, with a maximum number of 10 factors and a load factor of $\alpha=.95$, also as the main factor of analysis communalities = multiple $\mathrm{R} 2$ and the normalized Varimax rotation factor (De la Fuete, 2011).

\subsection{Comparative analysis}

The statistical method of analysis of variance (ANOVA) was used. The nominal variable of STATE was considered against the 40 interval variables considered in the instrument that was applied. The "One way" method was used with a significance level $\alpha=0.05$

\section{Results}

With the information obtained, it is intended to show a clear analysis of the research phenomenon in order to know the development of digital literacy in basic education students in virtual classes derived from the COVID-19 pandemic. According to descriptive statistics, the first task is to describe the data, values or scores obtained for each variable. Factor analysis and comparative analysis were used. Integrational or factor analysis works on variance and data reduction that works to locate homogeneous groups of variables from a set. Next, table 1 is presented, where the variables with a factorial load above 0.6 were selected.

\begin{tabular}{|c|c|}
\hline Variable & $\begin{array}{l}\text { Factorial } \\
\text { load }\end{array}$ \\
\hline Analysis of the use of digital media & 0.810248 \\
\hline $\begin{array}{l}\text { Knowledge on the part of the student and purpose } \\
\text { of the writing. }\end{array}$ & 0.715273 \\
\hline $\begin{array}{l}\text { Relationship of the development of reading and } \\
\text { writing with virtual education. }\end{array}$ & 0.778087 \\
\hline $\begin{array}{l}\text { Link learning to read with the ability to function } \\
\text { properly in the digital world. }\end{array}$ & 0.651487 \\
\hline $\begin{array}{l}\text { Digital media in the educational evaluation } \\
\text { process. }\end{array}$ & 0.798088 \\
\hline $\begin{array}{l}\text { Digital media in school and extracurricular } \\
\text { counseling. }\end{array}$ & 0.644477 \\
\hline $\begin{array}{l}\text { Strategies to help / teach citing sources and } \\
\text { preventing plagiarism. }\end{array}$ & 0.685015 \\
\hline $\begin{array}{l}\text { Use of digital media in the design of strategies that } \\
\text { promote active learning and comprehensive } \\
\text { training of students. }\end{array}$ & 0.737042 \\
\hline $\begin{array}{l}\text { Analysis of student access to selected } \\
\text { technological resources, so that it is equitable. }\end{array}$ & 0.733360 \\
\hline $\begin{array}{l}\text { I promote the understanding of the texts around the } \\
\text { sociocultural environment in which the text takes } \\
\text { place. }\end{array}$ & 0.826041 \\
\hline $\begin{array}{l}\text { I organize the contents of the reading in concept } \\
\text { maps, diagrams, drawings, pictograms, among } \\
\text { others. }\end{array}$ & 0.802478 \\
\hline $\begin{array}{l}\text { I encourage the use of reading material from } \\
\text { various current information sources, such as the } \\
\text { internet and the press. }\end{array}$ & 0.825759 \\
\hline
\end{tabular}

Table 1 Análisis de factores

Source: Self Made

GARZA-ROSALES, Gerardo de Jesús, VARGAS-LERMA, Jorge Fernando, MIRÓN-OROZCO Víctor Ilich and MARTÍNEZVILLALBA, José Antonio. Development of digital literacy in basic education through virtual classes derived from Covid-19. Journal of Computational Systems and ICTs. 2020 
In general terms, since virtual classes were implemented in Mexico derived from the pandemic, the teacher assesses the aptitudes, attitudes and cultural capital of the students before implementing activities that involve the use of digital media in the classes. Likewise, he guides the students in relation to the design of the text, informing about the purpose of each activity, asks them to use previous experiences to produce texts, encourages them to orally communicate their ideas regarding the content covered in the activity. In the same way, it promotes the understanding of the texts around the sociocultural context in which the text takes place and finally it is mentioned that to work the contents of the reading are organized in concept maps, diagrams, drawings, pictograms using tools and / or digital applications.

Despite the little experience and training that teachers had in the virtual world, it is shown that the teacher uses digital media in different school activities, to advise and solve extracurricular situations. Under this same theme, he seeks with its application active learning and comprehensive training of students, reflects on the benefits and / or difficulties involved in the use of digital media in the learning processes of students.

The digital literacy processes are considered as a type of competence of great importance in the teaching and learning processes of teachers. Given that this type of competences allows subjects to obtain information for later use and scriptural communication (Caro and Arbeláez, 2009; Zavala, 2011), it is also considered as an instrument of educational processes, a competence to relate to others in daily life or an essential tool in the construction of new knowledge

In virtual education, the teacher participates in work networks that promote the integration of digital media in the planning, development and evaluation of their classes, generates ideas and offers suggestions that allow the updating of the technological resources that the school has.

According to Martínez-Garcés and Garcés-Fuenmayor (2020), pertinent and strengthening strategies must be implemented in a preventive manner to achieve an innovative level of competencies for the processes developed by teachers.
To achieve meaningful learning, the teacher asks students to make connections between what they read and the world around them. She guides them in the development of writing with the ability to function adequately in the digital world. Although nowadays these tasks are carried out in the virtual context (use of search engines, text annotation tools, etc.), their acquisition is not linked to the computer skills of the users, but to a structure and logic of thought that allows the user to undertake searches of academic documents to break them down and create a constructive criticism that leads to the generation of meaningful learning.

The contributions made by Marín and Luna (2020) showed that literacy in digital media is detailed by four main factors: age, initial profession, educational focus and specialty served. It is important to train and develop this type of skills for teacher training in this area.

Hernandez and collaborators (2018) detail that educational institutions were facing changes, where virtual innovation is one of the tools to consider to face the adaptations of society and the technological world that new generations are experiencing.

On the other hand, the results of the application of the instruments were also studied using the analysis of variance (ANOVA) that can determine if the means of three or more groups are different.

Considering that according to INEGI (2015) in the state of Oaxaca, out of every 100 people 15 years of age and older, only $84 \%$ know how to read and write a message, placing them in last place at the national level. This data does not guarantee a success in the implementation of virtual classes in this pandemic. However, teachers in Oaxaca made greater use of networks and integration of digital media in planning, as well as the constant updating of technological resources. Likewise, they have a greater development of writing in the digital world, as well as a greater understanding of the texts around their communicative function and show the ability to function in the digital world than teachers in Aguascalientes and Durango (See graph 1). 
Teachers living in the south of the country managed to establish agreements to develop their educational practice during the COVID-19 pandemic, considering their real situation and starting from it to make the necessary adjustments.

Teachers living in the south of the country managed to establish agreements to develop their educational practice during the COVID-19 pandemic, considering their real situation and starting from it to make the necessary adjustments.

An important aspect to consider that stipulates the (United Nations (UN) in its August 2020 report, is that it does not always include timely educational strategies to offer efficient distance education, causing a deficit in their learning. that it is pertinent that educational institutions find alternatives and offer training to teachers for an equal and inclusive education.

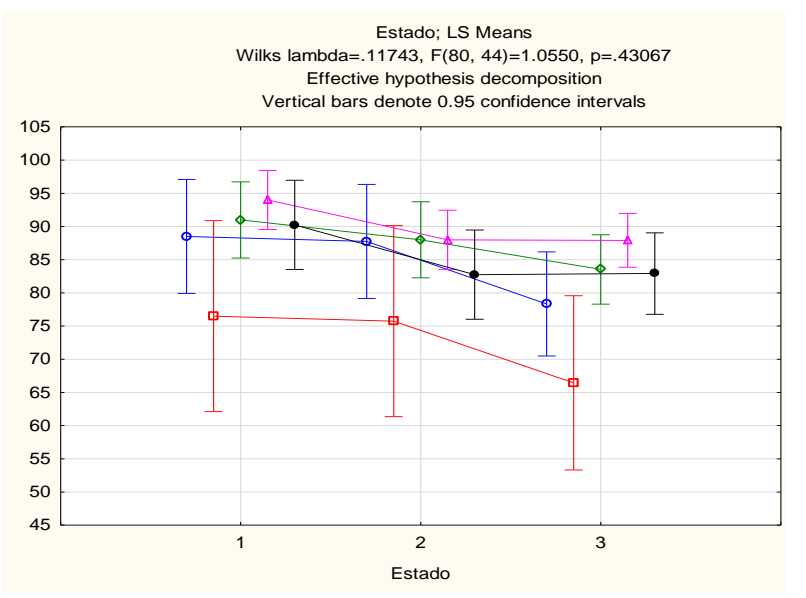

Graphic 1 ANOVA "One Way" analysis for the nominal variable "State" where the number represents: 1) Oaxaca, 2) Aguascalientes and 3) Durango. The ordinal variables are distributed as follows: (Red) counseling in digital media, (Blue) digital media in the educational process, (Green) digital literacy, (black) literacy in the digital world, and (Pink) reading of understanding

Considering that public education is the same for each state of Mexico, the reality is different, the educational process cannot be homogenized, if each state has different organizations not only economically but also socially. Therefore, considering that a single system or form of work in virtual education can develop learning in students is totally false. This depends on many aspects, some of them are the geographical location of the students, the material and / or technological equipment it has, the support from the parents, etc.
The same thing happens with teachers, adding aspects such as lack of practice in the use of technology, delivery time for jobs, long working hours, among others. According to Paredes-Chacín and collaborators (2020) the effects of COVID-19 marked a disruptive process in education. Therefore, to strengthen the transition process to an education to virtual media, it is important to train teachers and students, as well as investment in technologies in order to improve the teaching-learning process. Although the latter is not a guarantee or viable for various educational institutions.

Similarly, some applications such as Whats App and You Tube have served as support in Mobile Learning technology (mlearning) and its use has increased in virtual subjects as a mechanism of innovation and entrepreneurship as a means of response to health crisis (Rodríguez and Formoso, 2020).

\section{Acknowledgments}

We are grateful for the support from Dr. José Rubén Román Ortiz (DGETI), Dr. Francisco López González (SEP) and Lic. José Luis Villagrana González (UANE, Torreón), for their support in the distribution of the instruments of the research with teachers from the states of Oaxaca, Aguascalientes and Durango.

\section{Conclusions}

By carrying out the methodological development proposed in this research, it has been possible to reflect on the influence of the use of digital media in virtual education derived from the COVID-19 pandemic for the development of digital literacy of elementary school students.

Social confinement has made it possible to generalize virtual education, according to Gros and García-Peñalvo (2016) as "an increasingly important way of learning and teaching in recent decades and has been recognized as an efficient and effective learning method". For education in Mexico it was a new experience, different from what is generally used in basic education. Despite this, teachers and students overcame the difficulties in using virtual platforms and found that this type of education offers new learning opportunities in an interconnected society, where its use is necessary today. 
It is appropriate to reflect on current education at the basic level, due to social isolation, physical classrooms and distance education. For the moment, education has moved into the homes of students, but the tendency is to stay there. Learning spaces deserve to be transformed in order to guarantee the optimization of learning. Distance education means for students and teachers the development of responsibility, autonomy and a flexible option for teaching (González-Zamar and AbadSegura, 2020; Teba et al., 2020).

Teachers in virtual education work developed different skills to achieve student learning using tools such as audiovisual media. It is important to mention that before this modality the teachers managed to develop literacy in their group. This was achieved through a previous analysis of the student's situation, of all the curricular elements, of her needs and interests, visualizing the audiovisual media that were appropriate to achieve learning.

On the other hand, it will be a very complicated task to achieve optimal learning in virtual education, while there are inequalities, there are families where each member of the household has one or more computers, in others there is only one computer for the whole family, there being no other options but to alternate its use and in other cases the students connect to class from their cell phones.

This new mode of education requires certain conditions consistent with what Cabero (2006) stated, where it establishes that certain mastery of information technology by teachers and students are related to skills for autonomous learning; knowledge of applications, willingness to change and excellent internet connection.

Finally, the importance of developing in future research aspects that allow the monitoring and evaluation of educational practices in virtual education is mentioned, since the return to classes will be blended (hybrid) and it is necessary to analyze the return, considering the strategies undertaken before, during and after the health crisis derived from the COVID-19 pandemic.

\section{References}

Barton, D., Hamilton, M., IvaniÚc, R., \& Ivanič, R. (2000). Situated literacies: Reading and writing in context. Londres, Inglaterra. Psychology Press.

Cabero, J. (2006). Bases pedagógicas del elearning. Revista de Universidad y Sociedad del Conocimiento, 3(1), 1-10. Doi: 10.7238/rusc.v3i1.265

Caro, L., \& Arbeláez, N. (2009). Hipertextualidad, literacidad y discurso académico: conceptos para la gestión del conocimiento en la red. Revista Virtual Universidad Católica del Norte. (28), 1-23.

Cassany, D. (2003). La lectura electrónica. Cultura y Educación 15(3):239-251.

Cassany, D. (2005). Los significados de la comprensión crítica. Lectura y Vida. 26(3), 3245.http://www.lecturayvida.fahce.unlp.edu.ar/n umeros/a26n3/26_03_Cassany.pdf

De la Fuente Fernández, S. (2011). Análisis Factorial Santiago de la Fuente Fernández. Recuperado de: https://www.fuenterrebollo.com/Economicas/E CONOMETRIA/MULTIVARIANTE/FACTO RIAL/analisis-factorial.pdf

Domínguez, J., Rama, C. \& Rodríguez, J. (2013). La educación a distancia en el Perú. Hacia la convergencia de las modalidades educativas. Lima, Perú. Editorial Gráfica Real S.A.C.

Dorfsman, M. (2012) La profesión docente en contextos de cambio: el docente global en la sociedad de la información. RED-DUSC. Revista de Educación a Distancia-Docencia Universitaria en la Sociedad del Conocimiento. Número 6. Murcia: Universidad de Murcia. Recuperado de: http://www.um.es/ead/reddusc/6/marcelo_dusc 6.pdf

Ferreiro, E. (1995). Diversidad y proceso de alfabetización: de la celebración a la toma de conciencia. Revista de ciencias sociales, (2), 919. Recuperado de: RIDAA-UNQ Repositorio Institucional Digital de Acceso Abierto de la Universidad Nacional de Quilmes http://ridaa.unq.edu.ar/handle/20.500.11807/13 62

GARZA-ROSALES, Gerardo de Jesús, VARGAS-LERMA, Jorge Fernando, MIRÓN-OROZCO Víctor Ilich and MARTÍNEZVILLALBA, José Antonio. Development of digital literacy in basic education through virtual classes derived from Covid-19. Journal of Computational Systems and ICTs. 2020 
Ferreiro, E. (1997). La revolución informática y los procesos de lectura y escritura. Estudios Avançados, 11(29), 277-285. Doi: 10.1590/S0103-40141997000100015

Ferreiro, E. (2013). El ingreso a la escritura y a las culturas de lo escrito. Ciudad de México, México. Siglo XXI Editores.

Freire, P. (2004). La importancia de leer y el proceso de liberación. Ciudad de México, México. Siglo XXI Editores.

García, L. (2014). Bases, mediaciones y futuro de la Educación a distancia en la sociedad digital. Revista Iberoamericana de Educación a Distancia. 17(1) 233-234.

González, F. (2011). Inclusión y atención al alumnado con necesidades educativas especiales en España. Participación educativa, (18), 60-78. Recuperado

de: https://sid.usal.es/idocs/F8/ART19368/gonzalez _gil_18.pdf

González-Zamar, M. D., \& Abad-Segura, E. (2020). Diseño del espacio educativo universitario y su impacto en el proceso académico: análisis de tendencias. Revista De Estilos De Aprendizaje, 13(25), 1-13

Gros, B. \& García-Peñalvo, F.J. (2016) Future Trends in the Design Strategies and Technological Affordances of E-Learning. In: Spector M., Lockee B., Childress M. (Eds) Learning, Design, and Technology. Springer, Cham. Doi: 10.1007/978-3-319-17727-4_67-1

Hernández, R., Fernández, C. y Baptista, P. (2008). Metodología de la investigación. Ciudad de México: McGraw-Hill.

Hernández, V., Fernández, K., \& Pulido, J. (2018). La actitud hacia la educación en línea en estudiantes universitarios. Revista de Investigación Educativa, 36(2), 349-364. Doi: 10.6018/rie.36.2.277451

Instituto Nacional de Estadística y Geografía INEGI (2015). Encuesta Intercensal 2015. Recuperado de: https://www.inegi.org.mx/programas/intercensa 1/2015/
Levratto, V. (2014). Arquilectur@: modalidades de lectura en la web (Tesis doctoral). Universidad Nacional de Educación a Distancia, UNED, España. Recuperado de: http://espacio.uned.es/fez/eserv/tesisuned:EducacionVlevratto/LEVRATTO_Valeria_Tesis.pdf

Mampaso, J., \& Carrascal, S. (2020). El espacio como elemento facilitador del aprendizaje y de atención a la diversidad. Revista De Estilos De Aprendizaje, 13(25), 1-3. Recuperado de: http://revistaestilosdeaprendizaje.com/article/vi ew/2092

Marín, J. G. y Luna M. E. (2020) Educación normal y enseñanza a distancia: literacidades digitales docentes ante la emergencia sanitaria COVID-19. Práctica Docente. Revista de Investigación Educativa, 2(4), 11-33

Martín-Barbero, S. (2020). COVID-19 has accelerated the digital transformation of higher education. World Economic Forum (WEF Agenda-blog). Recuperado de: https://www.weforum.org/agenda/2020/07/covi d-19-digital-transformation-highereducation/

Martínez-Garcés, J., \& Garcés-Fuenmayor, J. (2020). Competencias digitales docentes y el reto de la educación virtual derivado de la covid19. Educación y Humanismo, 22(39), 1-16. Doi: 10.17081/eduhum.22.39.4114

McLuhan, M. (2011). Comprender los medios de comunicación. Las extensiones del ser humano. Barcelona, España. Paidos Ibérica S.A.

Moore, G. A. (1996). Crossing the Chasm. Nueva York, Estados Unidos. Harper Business.

Nieto, R. A. (2012). Educación virtual o virtualidad de la educación. Revista Historia de la Educación Latinoamericana, 14(19). 137150. Doi: 10.9757/Rhela.19.06

OECD (2018). Effective Teacher Policies: Insights from PISA. OECD Publishing, Paris. Recuperado de: https://doi.org/10.1787/9789264301603-en 
Organización de las Naciones Unidas (Agosto, 2020) Informe de políticas: La educación durante la COVID-19 y después de ella. Recuperado de: https://www.un.org/sites/un2.un.org/files/policy _brief_-_education_during_covid-

19_and_beyond_spanish.pdf

Paredes-Chacín, A., Inciarte, A. y WallesPeñaloza, D. (2020). Educación superior e investigación en Latinoamérica: Transición al uso de tecnologías digitales por Covid-19. Revista de Ciencias Sociales (Ve), XXVI(3), 98117. Doi: $10.31876 /$ rcs.v26i3.33236

Pérez, M. (Noviembre 2004). Leer, escribir, participar: un reto para la escuela, una condición de política. Congreso Nacional de Lectura Fundalectura. Bogotá, Colombia.

Rodríguez, R., \& Formoso, A. A. (2020). Efectos de YouTube y WhatsApp en procesos de enseñanza - aprendizaje ante el nuevo coronavirus. Revista Conrado, 16(77), 346-353.

Teba, E. M., Caballero P. A., \& Bueno, Á. (2020). SHINE®: modelo para la transformación de espacios educativos. Revista de Estilos de Aprendizaje, 13(25), 14-28.

Zavala, V. (2011). La escritura académica y la agencia de los sujetos. Cuadernos Comillas.1(56), 52-66. 